\title{
Durability Indicators in High Absorption Recycled Aggregate Concrete
}

\author{
Luis F. Jiménez ${ }^{1}$ and Eric I. Moreno ${ }^{2}$ \\ ${ }^{1}$ Chetumal Institute of Technology, Avenida Insurgentes No. 330, 77050 Chetumal, QROO, Mexico \\ ${ }^{2}$ College of Engineering, Universidad Autónoma de Yucatán, Avenida Industrias No Contaminantes s/n por Anillo Periférico Norte, \\ 97110 Mérida, YUC, Mexico
}

Correspondence should be addressed to Luis F. Jiménez; fjtorrez@itchetumal.edu.mx

Received 5 December 2014; Accepted 3 March 2015

Academic Editor: Robert Cerný

Copyright (C) 2015 L. F. Jiménez and E. I. Moreno. This is an open access article distributed under the Creative Commons Attribution License, which permits unrestricted use, distribution, and reproduction in any medium, provided the original work is properly cited.

\begin{abstract}
The use of recycled aggregates in structural concrete production has the inconvenience of increasing the fluid transport properties, such as porosity, sorptivity, and permeability, which reduces the resistance against penetration of environmental loads such as carbon dioxide and chloride ion. In this paper, behavior of ten concrete mixtures with different percentages of coarse aggregate replacement was studied. The recycled material was recovered by crushing of concrete rubble and had high absorption values. The results showed that it is possible to achieve good resistance to carbonation and chloride penetration with up to $50 \%$ replacement of recycled coarse aggregate for 0.5 water/cement ratio. Finally, new indexes for porosity and sorptivity were proposed to assess the quality of concrete.
\end{abstract}

\section{Introduction}

Concrete is a fully recyclable material, provided it is not contaminated. Recycled concrete has been used in many nonstructural forms, even for treatment of acidic groundwater [1]. It can be used as structural material as long as it complies with the specifications for normal concrete. However, the manufacture of concrete elements with recycled aggregate from construction and demolition debris can have the drawback of high porosity and permeability, which facilitates the penetration of environmental loads such as chloride ions and carbon dioxide, causing chemical reactions that lead to corrosion of reinforcing steel, thus affecting its durability.

The durability of concrete is defined as the ability to withstand the effects of time, chemical attack, abrasion, or other degradation process. Durable concrete must retain its original shape, quality, and service conditions when exposed to the environment [2].

A variety of tests are available for the study of the durability of concrete, which require specialized equipment and methods of study, as well as long periods of exposure to observe deleterious effects. In the case of recycled aggregate concrete, several researches have been focused on the study of mechanical properties, often omitting durability aspects.

In this work, three fluid transport properties were determined in concrete indirectly related to durability, such as porosity, sorptivity, and air permeability. Two direct indicators were also analyzed, carbonation, and chloride penetration. Results are compared with indexes reported in the literature to determine the amount of coarse aggregate that may be replaced.

\section{Porosity}

The deterioration of concrete by non-mechanical causes is mainly due to the presence of water with dissolved harmful substances. Penetration and transport of water into the concrete takes place through the pores and cracks in the material and depends on the type, size and distribution of such voids. When using recycled aggregates in concrete 
TABLE 1: Suggested ranges for sorptivity in recycled aggregate concrete.

\begin{tabular}{lc}
\hline Sorptivity $\left(\mathrm{mm} / \mathrm{h}^{0.5}\right)$ & Durability class \\
\hline$<6.0$ & Excellent \\
$6.0-10.0$ & Good \\
$10.0-15.0$ & Poor \\
$>15.0$ & Very poor \\
\hline
\end{tabular}

production, an increment in porosity, permeability, and water absorption values can be expected.

Porosity has a great influence on the mechanical and durability properties of concrete. It represents the total voids in the material (cement paste plus aggregates). Porosity of the cement paste is the sum of the capillary and gel pore volume and represents the voids from solid components of the hydrated cement paste. In aggregates, the pore size varies in a wide range, but even the smallest pores are greater than gel pores in cement paste. Some pores are totally immersed within the particle, but others are open to the surface allowing the entry of water and other aggressive agents [4]. Given that the aggregate represents three quarters of the concrete volume, the rock's quality would be an important factor in porosity. However, it is the capillary porosity the one that influences the concrete durability as the cement paste surrounds the aggregate particles. According to CEB [5], the quality of the concrete in terms of porosity is classified as good if it is below $15 \%$, moderate if it is between 15 and $17 \%$, and poor if it is over $17 \%$.

\section{Sorptivity}

Sorptivity in a concrete sample gives a value of the effective porosity. It represents the increase in mass of the specimen as a result of water absorption by the capillary pores. It can be an important parameter to measure performance of concrete to the effect of environmental loads. Ho and Lewis [6] recommend a value less than or equal to $3 \mathrm{~mm} / \mathrm{h}^{0.5}$ for up to $30 \mathrm{~mm}$ coatings in severe conditions and up to $6 \mathrm{~mm} / \mathrm{h}^{0.5}$ in less aggressive environments. Other authors such as Olorunsogo and Padayachee [7] have rated sorptivity for recycled aggregate concrete in ranges shown in Table 1.

\section{Permeability}

Permeability tests on concrete are made to determine a coefficient describing the flow of liquids or gases through the pores of the material. A method available is the air permeability, included in the Swiss Standard SIA 262/1-GB: 2003 [8]. It is based on creating a vacuum within a double chamber cell which is placed on the concrete surface and measuring the speed with which the pressure returns to the atmospheric value. The application of this method allows to obtain the air permeability coefficient $(k T)$ describing the quality of the concrete surface according to the ranges given in Table 2.
TABLE 2: Quality of permeable concrete surface [3].

\begin{tabular}{lc}
\hline$k T\left(10^{-16} \mathrm{~m}^{2}\right)$ & Quality \\
\hline$<0.01$ & Excellent \\
$0.01-0.1$ & Very good \\
$0.1-1$ & Normal \\
$1-10$ & Poor \\
$>10$ & Very poor \\
\hline
\end{tabular}

\section{Carbonation}

In concrete structures, a major cause of deterioration is the reaction between the hydrated products of the cement paste and the carbon dioxide present in the atmosphere. This reaction reduces the $\mathrm{pH}$ of the pore solution, thus resulting in corrosion of the reinforcing steel bars which in the end decreases the service life of the structure. The resistance to a reduction in pore solution $\mathrm{pH}$ depends on the cementitious binder and it is strongly related to its acid neutralization capacity [9]. Since carbonation process can be very slow, for research purposes, the use of an acceleration chamber with controlled internal environment was chosen [10]. Carbonation depth are usually determined by colorimetry spraying an acid-base indicator on a freshly cut sample. According to literature [11] carbonation coefficient must not exceed the critical value of $6 \mathrm{~mm} / \mathrm{anno}^{0.5}$; coefficients above this value denotes low carbonation resistance.

\section{Chloride Penetration}

Chloride ion $\left(\mathrm{Cl}^{-}\right)$is the principal agent capable of causing corrosion process on steel reinforcement embedded in concrete elements and thereby reducing its durability. Chloride penetration in concrete can occur by diffusion if the element is submerged in salt water or by capillary suction if it is exposed to marine aerosol. In laboratory, the effect can be induced by immersion of the samples in synthetic sea water, by exposure in a salt spray chamber or by migration of chlorides, forcing its entry under the action of an external electric field. For durability purposes, the accepted $\mathrm{Cl}^{-}$ concentration should not exceed $0.4 \%$ by weight of cement [11].

\section{Materials and Methods}

7.1. Materials. The experiment consisted of a study of ten concrete mixtures combining two water/cement ratios $(\mathrm{w} / \mathrm{c})$ with five replacement rates of recycled coarse aggregate $(\% R)$. The w/c ratios were chosen to represent the highest w/c suitable for durability (0.5) and the highest w/c suitable for strength (0.7). The materials used were OPC, water, coarse aggregate and fine aggregate, obtained by crushing limestone from a local quarry, and recycled coarse aggregate recovered by cutting and grinding heterogeneous structural concrete rubble. Aggregate properties were determined according to ASTM Standards [12]. They can be seen in Table 3.

Highlights are the low specific gravity of all aggregates, as well as the high absorption values (above 6\%). However, 
TABle 3: Aggregate properties.

\begin{tabular}{llc}
\hline Material & Property & Value \\
\hline \multirow{3}{*}{ Normal coarse } & Maximum size & $19 \mathrm{~mm}$ \\
aggregate & Specific gravity & 2.33 \\
& Coose unit weight & $1187 \mathrm{~kg} / \mathrm{m}^{3}$ \\
& Absorption & $1401 \mathrm{~kg} / \mathrm{m}^{3}$ \\
& Maximum size & $6.7 \%$ \\
\hline \multirow{2}{*}{ Recycled coarse } & Specific gravity & $19 \mathrm{~mm}$ \\
aggregate & Loose unit weight & 2.31 \\
& Compact unit weight & $1102 \mathrm{~kg} / \mathrm{m}^{3}$ \\
& Absorption & $1235 \mathrm{~kg} / \mathrm{m}^{3}$ \\
\multirow{2}{*}{ Normal fine } & Specific gravity & $7.2 \%$ \\
aggregate & Fineness modulus & 2.38 \\
& Absorption & 2.4 \\
& & $6.2 \%$ \\
\hline
\end{tabular}

according to Solís-Carcaño and Moreno [13], these properties for normal and recycled aggregates can be located in the boundary between limestone materials of good and poor quality.

7.2. Mixture Design. Mixture design was performed based on the ACI method [14]. Each concrete mixture was designated with NC (normal concrete) or RC (recycled concrete) followed by $\% R(25,50,75$, or 100$)$. The last digit was added to define w/c ( 5 for 0.5 and 7 for 0.7). Effective absorption of $80 \%$ for the mixing water correction was considered. The relative amounts of the materials for each mixture, before daily moisture corrections, are indicated in Table 4.

7.3. Test Specimens. The concrete batches were 120 liters made in 8 minutes. Cylindrical specimens of $10 \times 20 \mathrm{~cm}$ were cast for porosity and sorptivity tests and $7.5 \times 15 \mathrm{~cm}$ for carbonation tests. Also, prismatic beams of $10 \times 15 \times$ $60 \mathrm{~cm}$ were cast for testing air permeability and penetration of chlorides. The specimens were subjected to a process of moist curing by immersion for 28 days and then conditioned at lab environment ( $80 \% \mathrm{RH}$ and $\left.28^{\circ} \mathrm{C}\right)$ for 90 days before carrying out tests for porosity, sorptivity, and air permeability.

7.4. Porosity, Sorptivity, and Air Permeability Tests. Porosity was determined using dry weight, saturated weight, and submerged weight of five test specimens following ASTM C 64206 [15]. For each sorptivity test 3 slices, $5 \mathrm{~cm}$ thick, were cut. In each slice a layer of epoxy paint was applied on all sides except for the exposed face to allow the entry of water by capillary suction in one direction. Norwegian method purposed by Fagerlund [16] was used. The air permeability tests were performed with double vacuum chamber equipment on three beams for each mixture and in three areas for each exposed face.

7.5. Carbonation and Chloride Penetration Tests. The specimens were exposed to carbonation for ten weeks in an acceleration chamber with $65 \%$ relative humidity and $4 \%$ $\mathrm{CO}_{2}$. The specimens were removed progressively from the chamber after 14, 35, 56, and 70 days of exposure and cut with

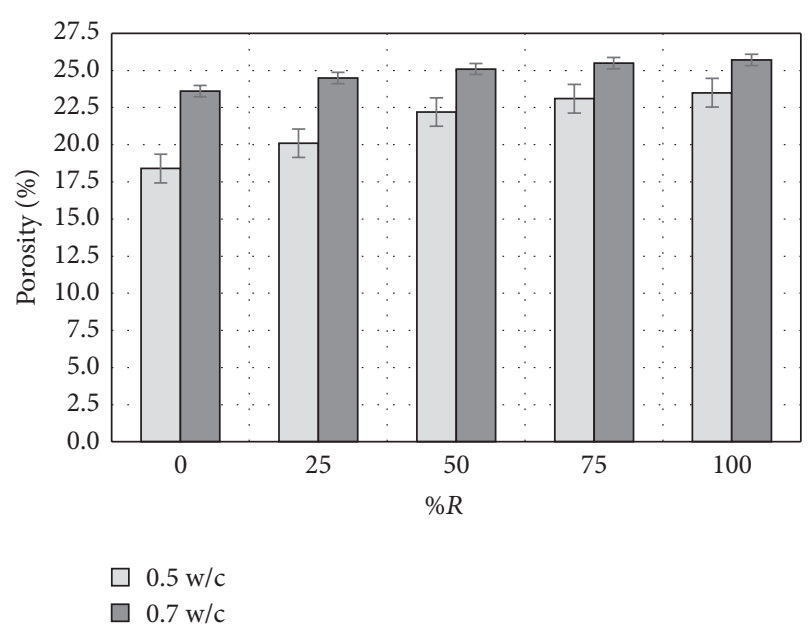

Figure 1: Porosity versus $\% R$.

a chisel and hammer. Carbonation depth measurements were performed using a digital caliper after spraying an acid-base indicator ( $1 \%$ phenolphthalein solution) according to RILEM procedure [17].

The specimens for chloride penetration were immersed for ten weeks in synthetic seawater, prepared in a similar manner as specified in ASTM D 1141-98 [18]. Except for the exposed face, all specimens were precoated with epoxy paint, to allow entry of chloride in only one way. After that period the specimens were drilled on the exposed face in eight layers, to extract concrete dust at different depths up to $6 \mathrm{~cm}$. The obtained powder was subjected to digestion with nitric acid for the total chloride extraction. The amount of chloride by weight of cement was determined following the FDOT method [19].

\section{Results and Discussion}

Results of porosity and sorptivity for each mixture according to $\% R$ are shown in Figures 1 and 2. All porosity values were very similar and above the limit of $17 \%$, which indicates a poor quality concrete. These results are higher than the $12.5 \%$ reported by Buyle-Bodin and Hadjieva-Zaharieva [20] but similar to the $18-20 \%$ reported by Gómez-Soberón [21] for $0.5 \mathrm{w} / \mathrm{c}$. However, in the case of aggregates with high absorption, porosity is not a conclusive indicator of the concrete quality, and the use of other direct and indirect evidence is necessary to determine its performance in terms of durability [22].

Sorptivity was calculated with the following [16]:

$$
\begin{gathered}
S=\frac{1}{m^{0.5}}, \\
m=\frac{t}{z^{2}},
\end{gathered}
$$

where $S$ is the sorptivity $\left(\mathrm{mm} / \mathrm{h}^{0.5}\right) ; m$ is the resistance to water penetration $\left(\mathrm{s} / \mathrm{m}^{2}\right) ; t$ is the required time for capillary 
TABle 4: Mixture design $\left(\mathrm{kg} / \mathrm{m}^{3}\right)$.

\begin{tabular}{|c|c|c|c|c|c|c|c|}
\hline \multirow{2}{*}{ Mixture } & \multirow{2}{*}{$\mathrm{w} / \mathrm{c}$} & \multirow{2}{*}{$\% R$} & \multirow{2}{*}{ Water } & \multirow{2}{*}{ Cement } & \multicolumn{2}{|c|}{ Coarse aggregate } & \multirow{2}{*}{ Fine aggregate } \\
\hline & & & & & Normal & Recycled & \\
\hline NC5 & 0.5 & 0 & 205 & 410 & 987 & 0 & 527 \\
\hline RC25-5 & 0.5 & 25 & 205 & 410 & 719 & 240 & 556 \\
\hline RC50-5 & 0.5 & 50 & 205 & 410 & 465 & 465 & 580 \\
\hline RC75-5 & 0.5 & 75 & 205 & 410 & 226 & 677 & 609 \\
\hline $\mathrm{RC} 100-5$ & 0.5 & 100 & 205 & 410 & 0 & 874 & 635 \\
\hline NC7 & 0.7 & 0 & 205 & 293 & 987 & 0 & 615 \\
\hline RC25-7 & 0.7 & 25 & 205 & 293 & 719 & 240 & 644 \\
\hline RC50-7 & 0.7 & 50 & 205 & 293 & 465 & 465 & 669 \\
\hline RC75-7 & 0.7 & 75 & 205 & 293 & 226 & 677 & 698 \\
\hline RC100-7 & 0.7 & 100 & 205 & 293 & 0 & 874 & 723 \\
\hline
\end{tabular}

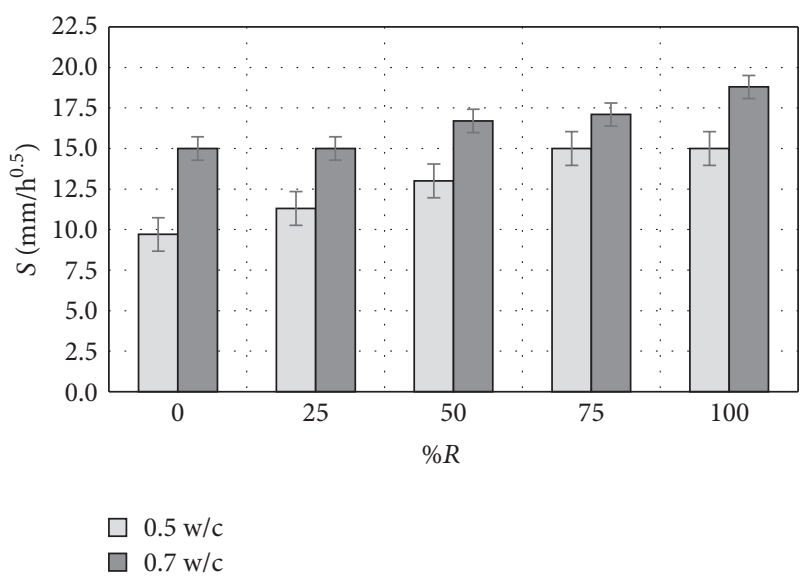

FIGURE 2: Sorptivity versus $\% R$.

ascension (s); and $z$ is the water penetration depth at time $t$ (m).

The sorptivity values increased slightly when $\% R$ increased. NC5 control concrete was the only below $10 \mathrm{~mm} / \mathrm{h}^{0.5}$. The remaining results for $0.5 \mathrm{w} / \mathrm{c}$ and those with 0 and $25 \% R$ for $0.7 \mathrm{w} / \mathrm{c}$ were in the range of $10-15 \mathrm{~mm} / \mathrm{h}^{0.5}$, classified as poor quality. The others were rated as very poor, above this range. Other researchers [7] have found similar results for equivalent conditions $\left(15-20 \mathrm{~mm} / \mathrm{h}^{0.5}\right.$ ).

In Figures 3 and 4 the air permeability coefficients $(k T)$ and carbonation coefficients converted to atmospheric values $\left(K_{c}\right)$ for the different $\% R$ are shown. In both tests the difference between the values from concrete specimens with $0.5 \mathrm{w} / \mathrm{c}$ to those with $0.7 \mathrm{w} / \mathrm{c}$ is noteworthy.

The model developed for the air permeability coefficient is based on the Hagen-Poiseuille law for elastic fluids, as shown in the following [23]:

$$
k T=\left(\frac{V_{c}}{A}\right)^{2} \frac{\mu}{2 \varepsilon P_{a}}\left(\frac{\ln \left(\left(P_{a}+\Delta P_{i}\right) /\left(P_{a}-\Delta P_{i}\right)\right)}{\sqrt{t_{f}}-\sqrt{t_{o}}}\right)^{2},
$$

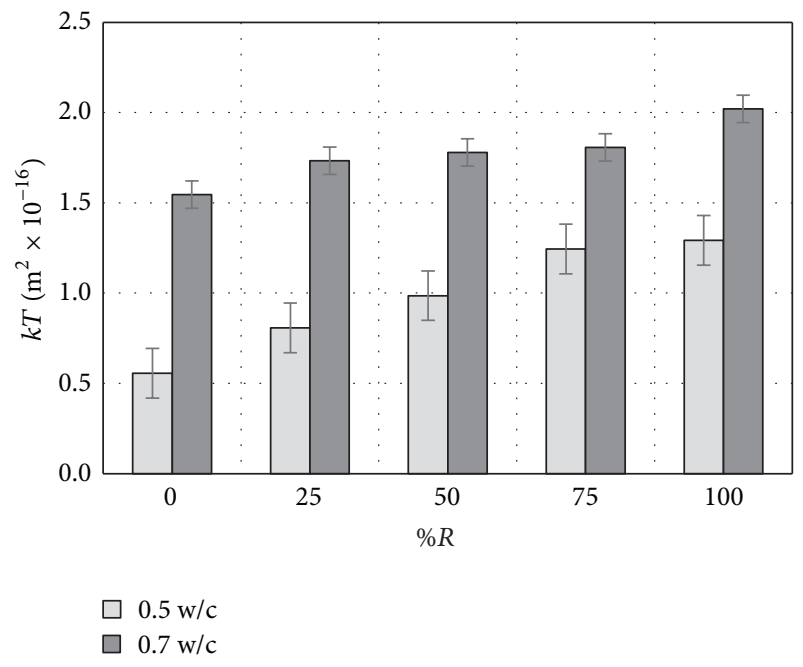

FIGURE 3: Air permeability versus $\% R$.

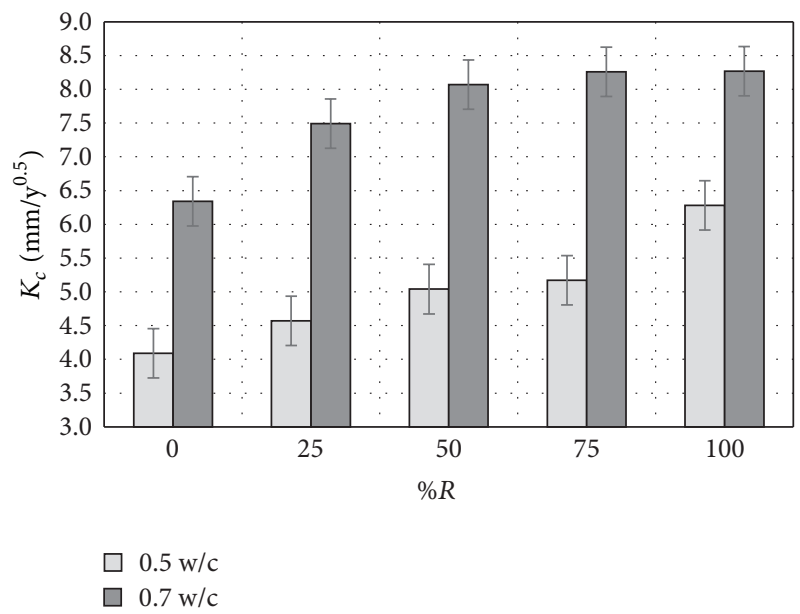

Figure 4: Carbonation versus $\% R$.

where $k T$ is the coefficient of air permeability $\left(\mathrm{m}^{2} \times 10^{-16}\right)$; $V_{c}$, the volume of the inner cell system $\left(\mathrm{m}^{3}\right) ; A$, the crosssectional area of the inner cell $\left(\mathrm{m}^{2}\right) ; \mu$, the viscosity of air at $20^{\circ} \mathrm{C}\left(2 \times 10^{-5} \mathrm{~N} \mathrm{~s} / \mathrm{m}^{2}\right) ; \varepsilon$, the estimated porosity of 
the cover concrete; $P_{a}$, the atmospheric pressure $\left(\mathrm{N} / \mathrm{m}^{2}\right) ; \Delta P_{i}$, the pressure rise in the inner cell at the end of the test $\left(\mathrm{N} / \mathrm{m}^{2}\right)$; $t_{f}$, the time at the end of the test (s); and $t_{0}$, the time at the beginning of the test $(60 \mathrm{~s})$.

Since the used equipment in these tests was calibrated by default to constant values of porosity equal to 0.15 , it was necessary to adjust the results provided by the device using actual porosity values that were previously determined.

The air permeability coefficients increased from 24 to $64 \%$ as the $\% R$ increased. $0.5 \mathrm{a} / \mathrm{c}$ concretes with 0,25 , and $50 \% R$ were in the range of $0.1<k T<1.0 \mathrm{~m}^{2} \times 10^{-16}$, that is considered normal quality. All other mixtures had values above $1.0 \mathrm{kT}$, indicating poor quality of the concrete surface.

Carbonation coefficients $\left(K_{c}\right)$ were obtained following the simplified model shown in the following [10]:

$$
\begin{aligned}
& K_{c}=K_{a} \sqrt{\frac{C_{a}}{C_{c}}}, \\
& K_{a}=\frac{\Sigma k_{i}\left(x_{i}-x_{0}\right)}{\sum x_{i}-i \cdot x_{0}},
\end{aligned}
$$

where $K_{c}$ is the carbonation coefficient converted to atmospheric value $\left(\mathrm{mm} / \mathrm{y}^{0.5}\right) ; K_{a}$ is the average of accelerated carbonation coefficients $\left(\mathrm{mm} / \mathrm{y}^{0.5}\right) ; C_{a}$ is the $\mathrm{CO}_{2}$ concentration outside the chamber $(0.051 \%) ; C_{c}$ is the $\mathrm{CO}_{2}$ concentration in the chamber (4\%); $k_{i}$ is the coefficient for the progress of carbonation depth $\left(\mathrm{mm} / \mathrm{y}^{0.5}\right) ; x_{i}$ is the carbonation depth $(\mathrm{mm}) ; x_{0}$ is the initial carbonation depth $(\mathrm{mm})$; and $i$ is thenumber of tests performed during the exposure period.

$K_{c}$ values increased according to the increase of $\% R$. $0.5 \mathrm{w} / \mathrm{c}$ concretes with 0 to $75 \% R$ achieved acceptable values between 4 and $6 \mathrm{~mm} / \mathrm{y}^{0.5}$; for the other mixtures, $K_{c}$ was above that range which shows poor resistance to carbonation.

When comparing outcomes between 0 and $100 \% R$, a variation of $35 \%$ for $0.5 \mathrm{w} / \mathrm{c}$ (although only $20 \%$ for $75 \% R$ ) and $23 \%$ for $0.7 \mathrm{w} / \mathrm{c}$ is observed. Other researchers have reported differences of $23 \%$ for $0.43 \mathrm{w} / \mathrm{c}$ [24], $17 \%$ for $0.6 \mathrm{w} / \mathrm{c}$ [25], $25 \%$ for $0.7 \mathrm{w} / \mathrm{c}$ [26], and $11 \%$ for $0.7 \mathrm{w} / \mathrm{c}$ [27]. An effective comparison of $K_{c}$ values is not possible, because the experimental procedures were different.

In Figures 5 and 6 the progress of carbonation depth versus time is modeled. For $0.5 \mathrm{w} / \mathrm{c}$ concretes, the worst result was for RC100-5, where at 25 years, carbonation depth would be $32.5 \mathrm{~mm}$. For $0.7 \mathrm{w} / \mathrm{c}$ concretes, carbonation depth at the same age would reach much higher values. These figures highlight the similarity between the carbonation behavior of mixtures RC100-5 and CN7; thus the worst $0.5 \mathrm{w} / \mathrm{c}$ mixture equals the best $0.7 \mathrm{w} / \mathrm{c}$ mixture.

In Figures 7 and 8, the relationship between the $K_{c}$ values with $S$ and $k T$ is analyzed, respectively. The correlation coefficients $(R)$ were greater than 0.9 indicating a relatively strong dependence between the studied variables in both cases.

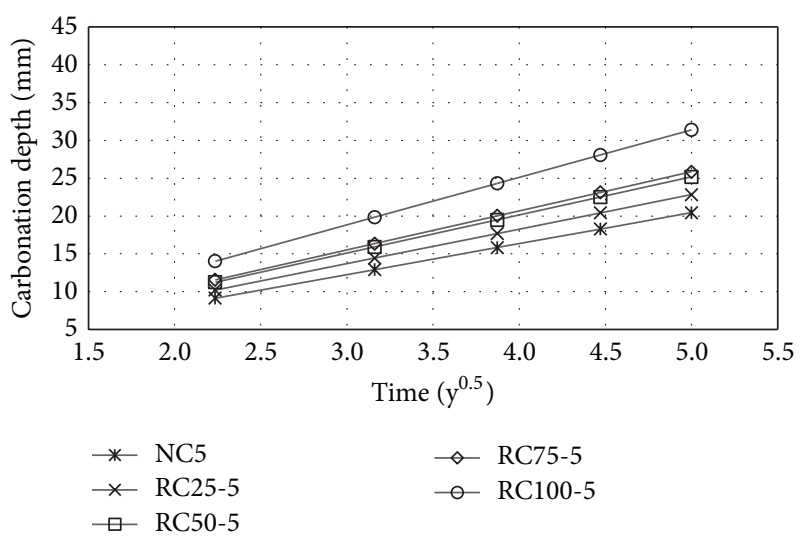

FIGURE 5: Calculated progress of carbonation depth versus time for $0.5 \mathrm{w} / \mathrm{c}$.

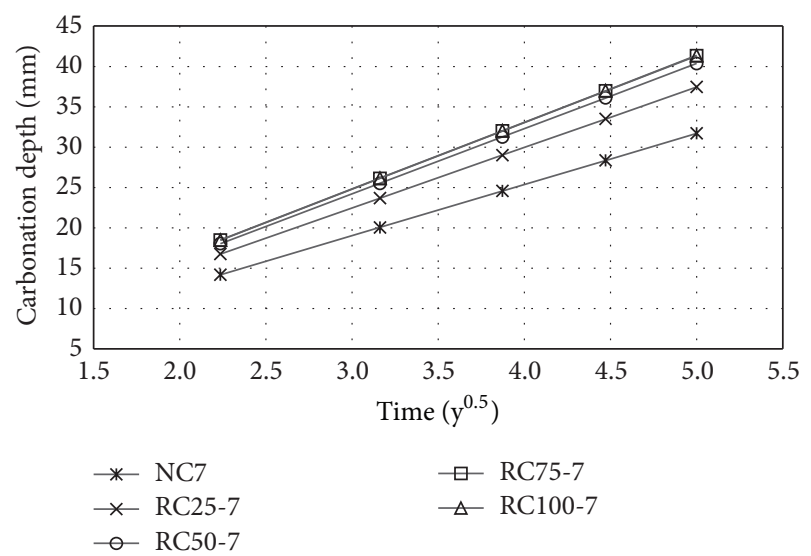

FiguRE 6: Calculated progress of carbonation depth versus time for $0.7 \mathrm{w} / \mathrm{c}$.

In Figures 9 and 10, chloride profiles by weight of cement at several depths are presented. The calculation was made from the following:

$$
\% \mathrm{Cl}=\frac{35.453 \mathrm{VN}}{10 \mathrm{~W}},
$$

where $\% \mathrm{Cl}$ is the chloride concentration by weight of concrete, $V$ is the intersection point of the potential's regression line with the $x$-axis of a Gran plot $(\mathrm{mV}), N$ is the silver nitrate normality, and $W$ is the sample weight $(\mathrm{g})$. The results were multiplied by the concrete/cement ratio to obtain the $\mathrm{Cl}^{-}$ concentration by weight of cement.

Mixtures with 0,25 , and $50 \% R$ reached chloride concentrations below permissible limit of $0.4 \%$ for $0.5 \mathrm{w} / \mathrm{c}$. Mixtures with 75 and $100 \% R$ and all the $0.7 \mathrm{w} / \mathrm{c}$ mixtures were well above the limit of $0.4 \%$. In all cases, a change in slope was observed at $2.5 \mathrm{~cm}$ depth, where there is a significant increase in the chlorides concentration.

The diffusion coefficients were calculated with (5), which gives solution to Fick's 2nd law in nonsteady state. Consider

$$
\frac{C s-C x}{C s-C o}=\operatorname{erf}\left(\frac{x}{2 D t}\right),
$$




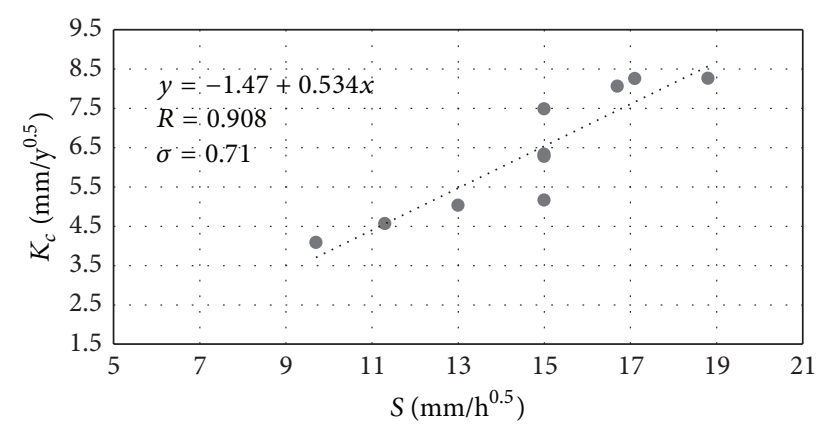

FIGURE 7: Carbonation versus sorptivity.

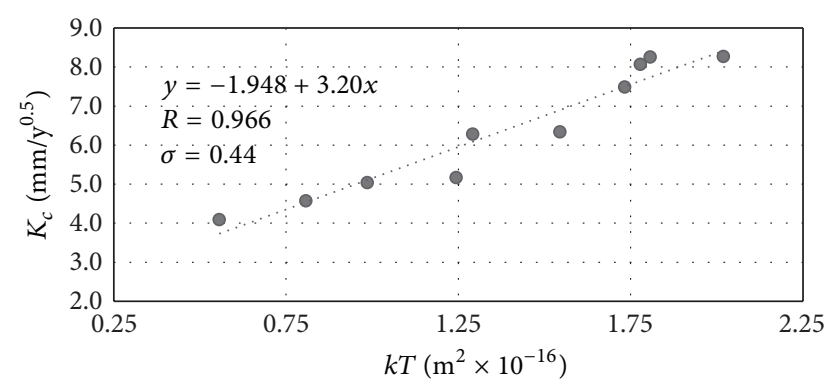

FIgURE 8: Carbonation versus air permeability.
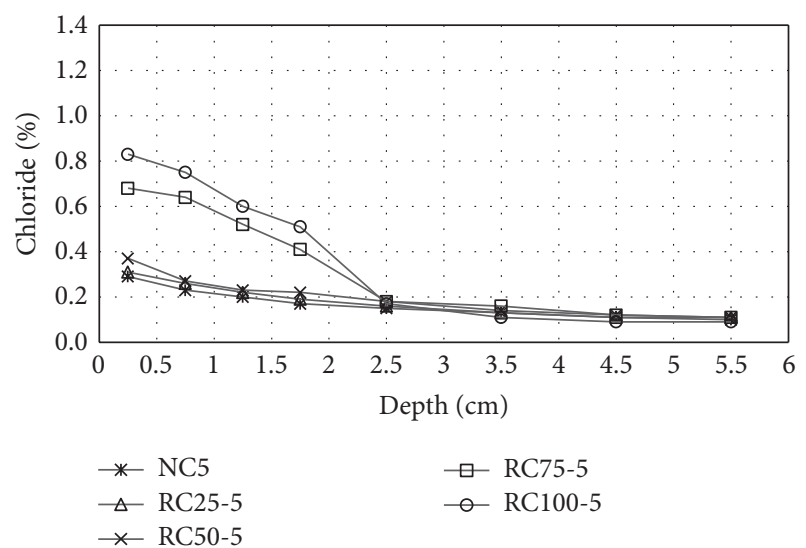

Figure 9: Chloride profiles for $0.5 \mathrm{w} / \mathrm{c}$.
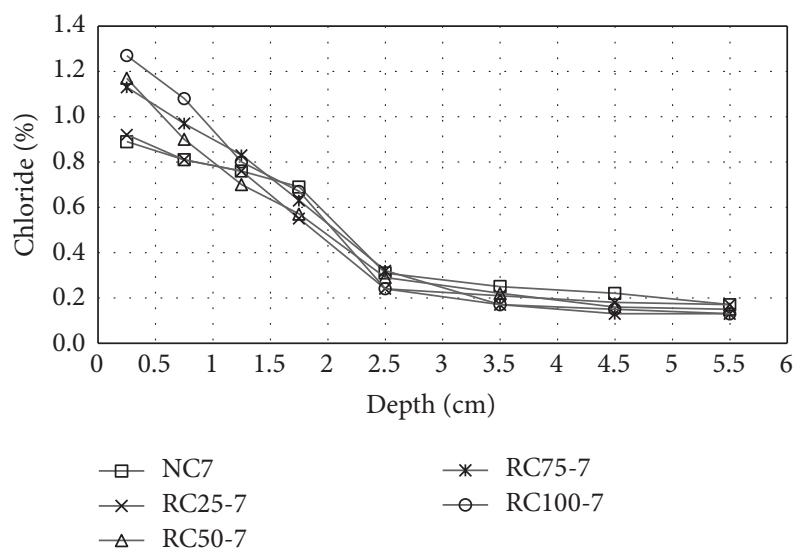

FIgURE 10: Chloride profiles for $0.7 \mathrm{w} / \mathrm{c}$.

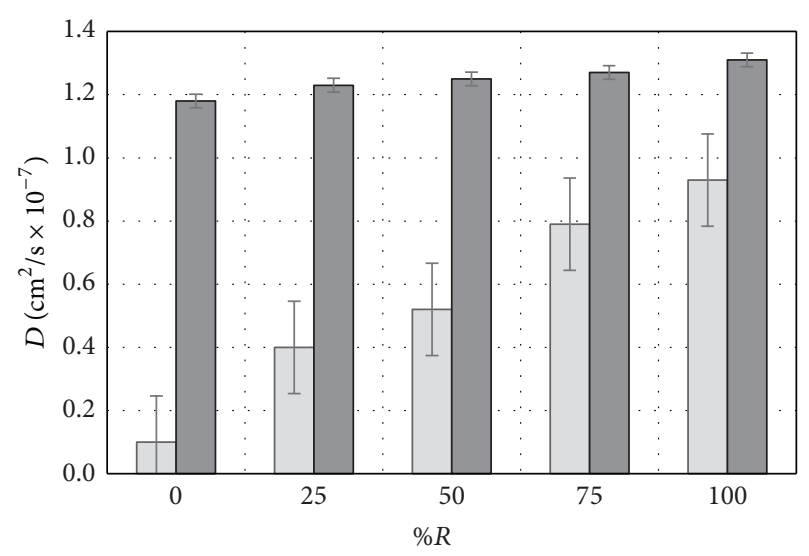

$\square 0.5 \mathrm{w} / \mathrm{c}$

$0.7 \mathrm{w} / \mathrm{c}$

Figure 11: Chloride diffusion versus $\% R$.

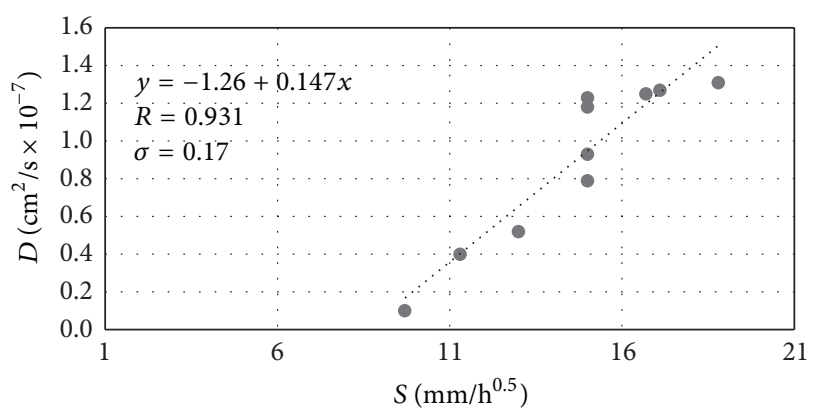

FIGURE 12: Chloride diffusion versus sorptivity.

TABLE 5: New suggested indexes for porosity and sorptivity in recycled aggregate concrete.

\begin{tabular}{lcc}
\hline Property & Index value & Class \\
\hline & $<15$ & Good \\
Porosity (\%) & $15-20$ & Moderate \\
& $>20$ & High \\
\hline & $<6$ & Good \\
Sorptivity $\left(\mathrm{mm} / \mathrm{h}^{0.5}\right)$ & $6-13$ & Moderate \\
& $13-18$ & Poor \\
& $>18$ & Very poor \\
\hline
\end{tabular}

where $D$ is the chloride diffusion coefficient $\left(\mathrm{cm}^{2} / \mathrm{s}\right) ; C s$ is the chloride surface concentration; $C o$ is the initial chloride concentration in concrete; $C x$ is the chloride concentration at depth $x$; and $t$ is the exposure time.

The results for each mixture can be compared in Figure 11, which shows that the diffusion coefficients were increasing according to $\% R$. The difference between 0 and $100 \% R$ was very strong $(89 \%)$ for $0.5 \mathrm{w} / \mathrm{c}$, while in concretes with $0.7 \mathrm{w} / \mathrm{c}$ it was only $10 \%$, which is attributed to poor quality concrete where $\% R$ do not have significance for these mixtures. Otsuki et al. [27] had reported differences of $17 \%$ for $0.55 \mathrm{w} / \mathrm{c}$ and $5 \%$ for $0.7 \mathrm{w} / \mathrm{c}$. 
TABLE 6: Durability indicators in recycled aggregate concrete.

\begin{tabular}{|c|c|c|c|c|c|c|c|}
\hline Mixture & $\mathrm{w} / \mathrm{c}$ & $\% R$ & Porosity & Sorptivity & $\begin{array}{c}\text { Air } \\
\text { permeability }\end{array}$ & $\begin{array}{l}\text { Carbonation } \\
\text { resistance }\end{array}$ & $\begin{array}{l}\text { Chloride } \\
\text { penetration } \\
\text { resistance }\end{array}$ \\
\hline CN5 & 0.5 & 0 & Moderate & Moderate & Normal & Moderate & Moderate \\
\hline CR25-5 & 0.5 & 25 & Moderate & Moderate & Normal & Moderate & Moderate \\
\hline CR50-5 & 0.5 & 50 & High & Moderate & Normal & Moderate & Moderate \\
\hline CR75-5 & 0.5 & 75 & High & Poor & High & Moderate & Poor \\
\hline CR100-5 & 0.5 & 100 & High & Poor & High & Poor & Poor \\
\hline CN7 & 0.7 & 0 & High & Poor & High & Poor & Poor \\
\hline CR25-7 & 0.7 & 25 & High & Poor & High & Poor & Poor \\
\hline CR50-7 & 0.7 & 50 & High & Poor & High & Poor & Poor \\
\hline CR75-7 & 0.7 & 75 & High & Poor & High & Poor & Poor \\
\hline CR100-7 & 0.7 & 100 & High & Very poor & High & Poor & Poor \\
\hline
\end{tabular}

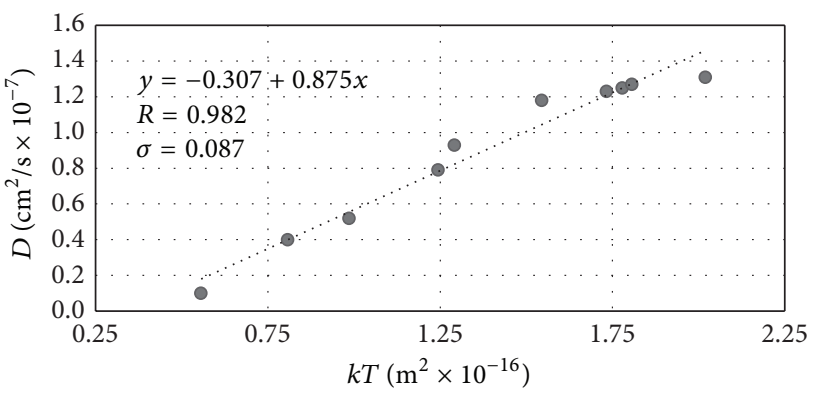

FIGURE 13: Chloride diffusion versus air permeability.

Recently, Amorim et al. [24] reported diffusion coefficients between $1.1 \times 10^{-7}$ and $1.4 \times 10^{-7} \mathrm{~cm}^{2} / \mathrm{s}$ for $0.43 \mathrm{w} / \mathrm{c}$, where the best outcome was for $50 \% R$, which were above the range obtained in this investigation for $0.5 \mathrm{w} / \mathrm{c}$.

In Figures 12 and 13, the statistical relationship between the chloride diffusion coefficients with sorptivity and air permeability can be seen. The correlation coefficients indicate a strong dependence between the studied variables, especially air permeability, where $R$ reaches the value of 0.98 .

Although high values of absorption, porosity, and sorptivity were reported in this paper, some mixtures showed acceptable performance in durability properties, so that new limits have been suggested in Table 5 .

Therefore, the behavior of recycled aggregate concrete in terms of durability when using high absorption aggregate, for different $\% R$ and $w / c$, could be classified according to that indicated in Table 6.

According to Table 6, it is possible to use up to $50 \%$ recycled coarse aggregate in $0.5 \mathrm{w} / \mathrm{c}$ mixtures to achieve acceptable durability conditions; higher replacement of coarse aggregate or mixtures with higher w/c ratio are not recommended.

\section{Conclusions}

The following conclusions can be assumed based on the following results. (i) The durability of concrete was reduced by the use of high absorption recycled coarse aggregate.

(ii) Concrete made with up to $50 \%$ aggregate replacement for $0.5 \mathrm{w} / \mathrm{c}$ had moderate resistance to carbonation and chloride penetration; higher replacement of coarse aggregate or mixtures with higher $\mathrm{w} / \mathrm{c}$ ratio are not recommended in terms of durability.

(iii) Carbonation and chloride diffusion in recycled aggregate concrete have strong statistical dependence with air permeability and sorptivity properties.

\section{Conflict of Interests}

The authors declare that there is no conflict of interests regarding the publication of this paper.

\section{Acknowledgments}

The authors would like to acknowledge the partial support for the development of research, granted by the Ministry of Education, through the SES-ANUIES Program.

\section{References}

[1] G. Regmi, B. Indraratna, L. D. Nghiem, A. Golab, and B. G. Prasad, "Treatment of acidic groundwater in acid sulfate soil terrain using recycled concrete: column experiments," Journal of Environmental Engineering, vol. 137, no. 6, pp. 433-443, 2011.

[2] ACI, 318: Building Code Requirements for Structural Concrete and Commentary, American Concrete Institute, Farmington Hills, Mich, USA, 2005.

[3] R. J. Torrent, "A two-chamber vacuum cell for measuring the coefficient of permeability to air of the concrete cover on site," Materials and Structures, vol. 25, no. 6, pp. 358-365, 1992.

[4] A. M. Neville and J. J. Brooks, Tecnología del Concreto, Trillas, Mexico City, Mexico, 1998.

[5] CEB, "Strategies for testing and assessment of concrete structures affected by reinforcement corrosion," CEB Bulletin No. 243, 1998. 
[6] D. W. S. Ho and R. K. Lewis, "The Water Sorptivity of Concretes. The Influence of constituents under curing," Durability of Building Materials, vol. 4, no. 3, pp. 241-252, 1987.

[7] F. T. Olorunsogo and N. Padayachee, "Performance of recycled aggregate concrete monitored by durability indexes," Cement and Concrete Research, vol. 32, no. 2, pp. 179-185, 2002.

[8] SIA, “Concrete structures," SIA 262/1-E: 2003, Swiss Society of Engineers and Architects, Zurich, Switzerland, 2003.

[9] G. K. Glass, B. Reddy, and N. R. Buenfeld, "Corrosion inhibition in concrete arising from its acid neutralisation capacity," Corrosion Science, vol. 42, no. 9, pp. 1587-1598, 2000.

[10] E. I. Moreno, "Carbonation coefficients from concrete made with high-absorption limestone aggregate," Advances in Materials Science and Engineering, vol. 2013, Article ID 734031, 4 pages, 2013.

[11] O. Trocónis, Manual for Inspecting, Evaluating and Diagnosing Corrosion in Reinforced Concrete Structures, CYTED, Maracaibo, Venezuela, 2000.

[12] ASTM Book of Standards, Construction: Concrete and Aggregates, vol. 04.02, ASTM Book of Standards, 2010.

[13] R. Solís-Carcaño and E. I. Moreno, "Evaluation of concrete made with crushed limestone aggregate based on ultrasonic pulse velocity," Construction and Building Materials, vol. 22, no. 6, pp. 1225-1231, 2008.

[14] ACI 211.2, Standard Practice for Selecting Proportions for Structural Lightweight Concrete, American Concrete Institute, Farmington Hills, Mich, USA, 1998.

[15] American Society for Testing and Materials, "Standard test method for density, absorption, and voids in hardened concrete," Tech. Rep. ASTM C 642-06, American Society for Testing and Materials, Philadelphia, Pa, USA, 2006.

[16] G. Fagerlund, "On the capillarity of concrete," Nordic Concrete Research, no. 1, paper no. 6, 1986.

[17] "CPC-18 Measurement of hardened concrete carbonation depth," Materials and Structures, vol. 21, no. 6, pp. 453-455, 1988.

[18] ASTM International, ASTM D 1141-98: Standard Practice for the Preparation of Substitute Ocean Water, American Society for Testing and Materials, West Conshohocken, Pa, USA, 1998.

[19] FDOT, Determining Low-Levels of Chloride in Concrete and Raw Materials, FM 5-516, Appendix C, FDOT, Tallahassee, Fla, USA, 2010.

[20] F. Buyle-Bodin and R. Hadjieva-Zaharieva, "Influence of industrially produced recycled aggregates on flow properties of concrete," Materials and Structures, vol. 35, no. 252, pp. 504-509, 2002.

[21] J. M. V. Gómez-Soberón, "Porosity of recycled concrete with substitution of recycled concrete aggregate: an experimental study," Cement and Concrete Research, vol. 32, no. 8, pp. 13011311, 2002.

[22] R. Solís-Carcaño and E. I. Moreno, "Análisis de la porosidad del concreto con agregado calizo," Revista de la Facultad de Ingeniería de la U.C.V., vol. 21, no. 3, pp. 57-68, 2006.

[23] R. Torrent, E. Denarié, F. Jacobs, A. Leemann, and T. Teruzzi, "Specification and site control of the permeability of the cover concrete: The Swiss approach," Materials and Corrosion, vol. 63, no. 12, pp. 1127-1133, 2012.

[24] P. Amorim, J. de Brito, and L. Evangelista, "Concrete made with coarse concrete aggregate: influence of curing on durability," ACI Materials Journal, vol. 109, no. 2, pp. 195-204, 2012.

[25] P. S. Lovato, E. Possan, D. C. C. D. Molin, Â. B. Masuero, and J. L. D. Ribeiro, "Modeling of mechanical properties and durability of recycled aggregate concretes," Construction and Building Materials, vol. 26, no. 1, pp. 437-447, 2012.

[26] S. M. Levy and P. Helene, "Durability of recycled aggregates concrete: a safe way to sustainable development," Cement and Concrete Research, vol. 34, no. 11, pp. 1975-1980, 2004.

[27] N. Otsuki, S.-I. Miyazato, and W. Yodsudjai, "Influence of recycled aggregate on interfacial transition zone, strength, chloride penetration and carbonation of concrete," Journal of Materials in Civil Engineering, vol. 15, no. 5, pp. 443-451, 2003. 

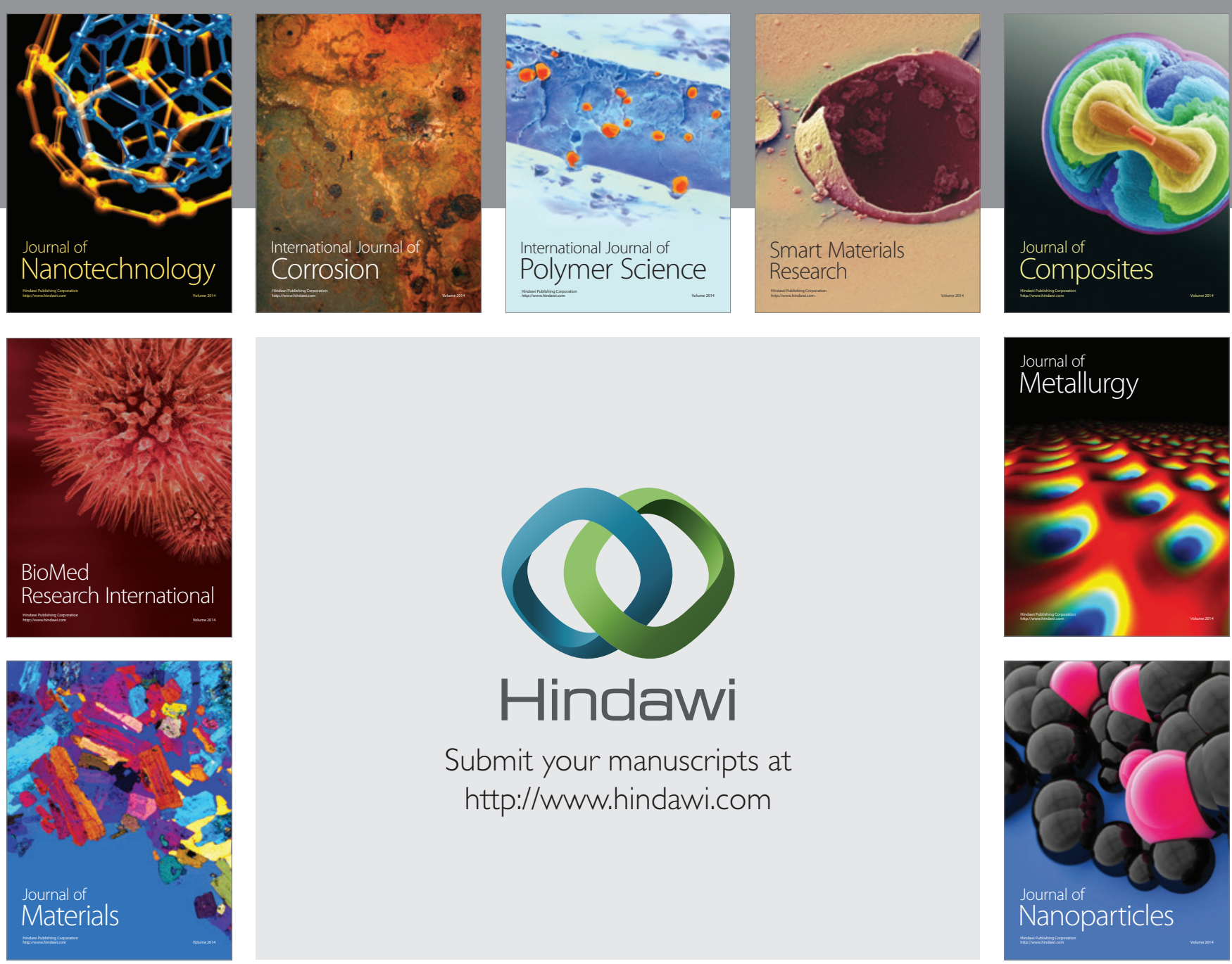

Submit your manuscripts at http://www.hindawi.com
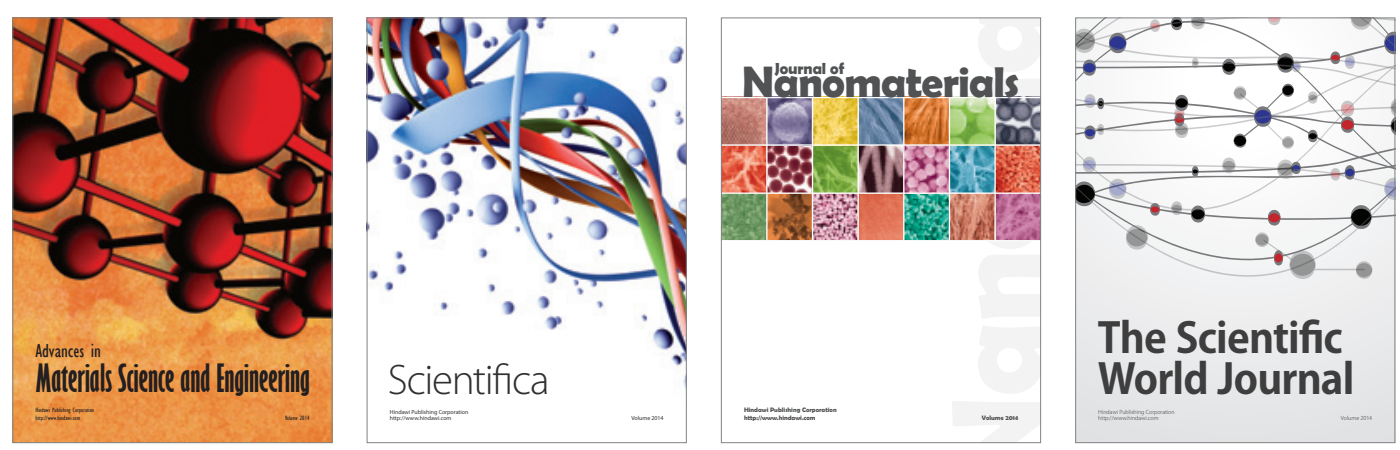

\section{The Scientific World Journal}
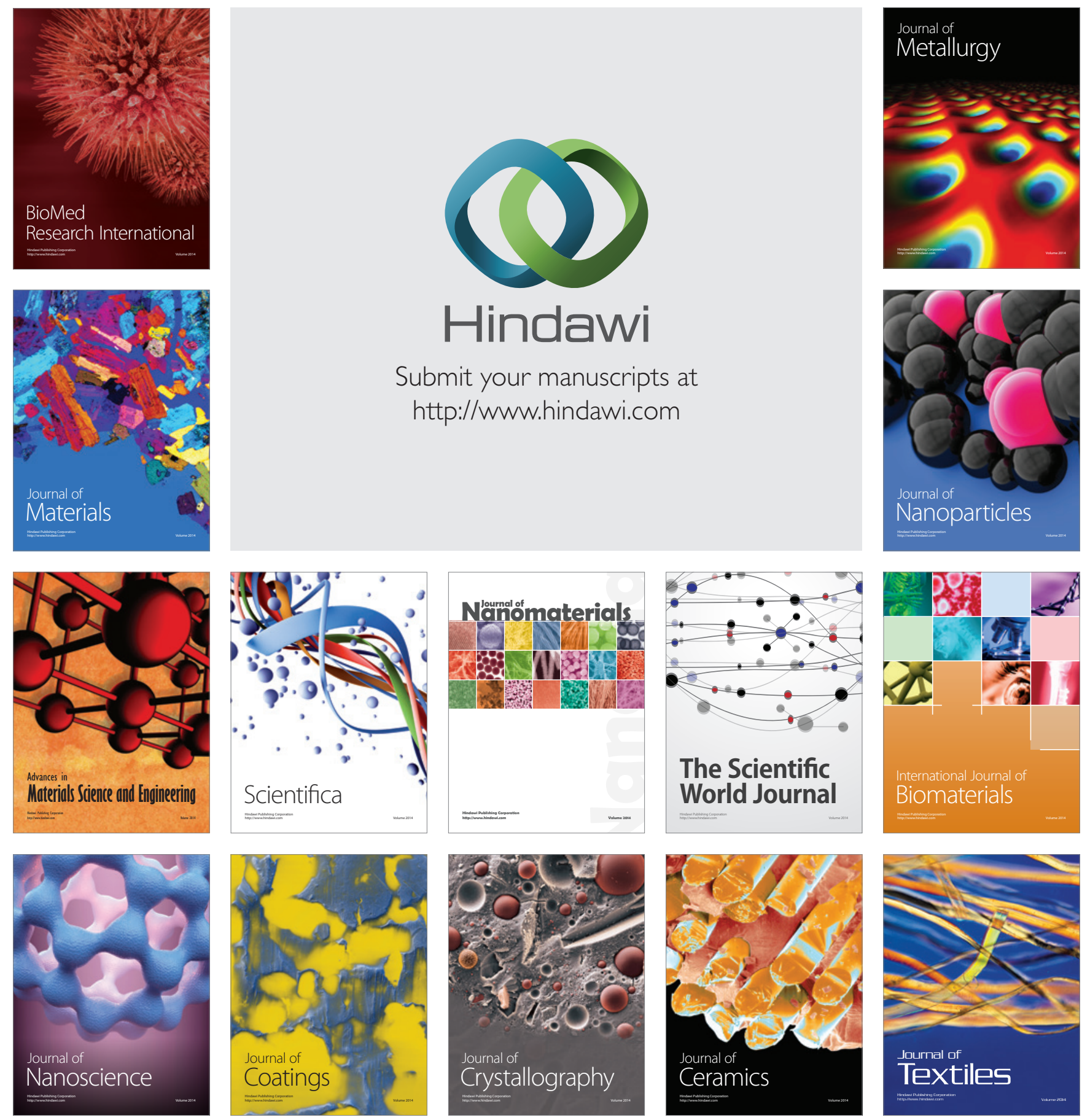